\title{
STUDYING THE MYTH OF WATER IN ANCIENT IRAN AND ITS RELATIONSHIP WITH RAIN-MAKING RITUALS
}

\author{
Hasan Goharpour \\ Department of Research in Art, Art and Architecture Faculty, Islamic Azad University Yazd Branch, \\ Yazd, Iran \\ Vahide Jalalkamali \\ Department of Research in Art, Art and Architecture Faculty, Islamic Azad University Yazd Branch, \\ Yazd, Iran
}

\begin{abstract}
Iran have always been conflicting with drought. As Dariush asks Ahura Mazda in his inscription in Takhte Jamshid to protect Iran from drought and lies. Creating myths is the first reaction of man's mind at the face natural disasters, because the primary human were confused in understanding the causes of these occurrences, thus, their reaction were infused with fear and this fear has caused them to assume a metaphysical god for each phenomenon and seek shelter from him. As time flows, it becomes clearer that myths are a land's valuable resources which can shed a light on the dark and unknown past. In the fables of creation, Water is one of the first things to be physically created and this is because of the significance of this life giving element. Thus, it is not far from expectation that the rain-making rituals and holding them during droughts have been always common in the ancient history of Iran.
\end{abstract}

Keywords: Myth, Water, Anahita, Rain-making ritual, Ancient Iran

\section{INTRODUCTION}

Myth originates with the word "Historia" meaning "story" and "History"; In the Greek language, "Mythos" means "Description", "News" and "Story" which shares a root with the word "Mouth" meaning "Expression", "Narration" and "Mouth".

The primary man, because of not understanding and the lack of dominance over nature and not knowing the causes of natural disasters such as eclipse, earthquake, drought, thunder and lightning, flood, seasonal changes and etc. have always been confused and as they didn't have the power to solve this confusion, based on their imaginations and thoughts, they would imagine a god for each of these phenomena. For each good phenomenon, there was a rewarding god with a beautiful and decent appearance, who could grant people their wishes. However, there were an unpleasant and petrifying god with an ugly and terrifying look for every evil phenomenon, whom people had to take shelter from the gracious gods and keep them satisfied with granting them sacrifices and gifts.

Thus, myth is a symbolic story about gods, angels and metaphysical creatures whom are present in a society's effort in describing the universe. Religious beliefs of the primary man begins with fables and in the latter eras they take the form of religions. Water which because of its significance in creation of life has always been one of the major rituals and beliefs of societies since the dawn of man. Rituals were held in the harsh days of drought in order for man to ask the god of water and rain for blessings to fall on the prayer's dry land.

\section{STATEMENT OF THE PROBLEM WATER IN THE FABLES OF CREATION}


Water is one of the classical elements (water, wind, earth, fire). The Persian word "آب" originates from "ab" in the Avestai language and from "apa" in Sanskrit, from the word "api" in ancient Persian and finally from the word "ap" in the language of Pahlavi.

Because of Water's significant role in the Iranian culture; it has been the root for many symbols, myths and rituals and since the ancient Mithraism era until today, this vital element has been mentioned in the folklores expressing the basic thoughts of Iranians. This life giving element has always been of great state and value in ancient Iranian's beliefs and it was accounted as a safe shelter for Zoroaster's children, whom Evil could never help but offence them. (Qureyshi, 2001: 221-226).

The significance of water in the minds of ancient Iranians is so much that the Greek historians have imputed the veneration and praise of water to Iranians. It is evident in the history of Herodotus, which is writer: "Iranians hold water much dear. They sacrifice and bring gifts for it as for other classic elements such as fire, wind, etc. They do not wash their hands in it and they do not defile it with filth." (Afifi, 1995: 402)

This element is of great position in the enlightening religion of Islam as well. Water heals and brings life to people and it is mentioned as "blessing" and "life giving" in the holy book of Quran. Aside from this, water plays an undeniable role in the Iranian culture. In original Iranian arts such as architecture and miniature, water is counted as a vital element.

Ancient Iranians used to pledge their vows to a number of holy elements including water. He who breaks a vow or is accused of breaking a promise must pass the test of Water or ritual tests (Amuzegar, 2007: 386).

Another role of this element is the role of purification and cleansing. In addition of external and seeming cleansing, water also cleanses women's womb and milk. In Rigveda, there are chants in praise of Apām Napāt (the name of the god of water in the religion of Zoroastrian). He is the offspring of waters. In Rigveda's chants, there are stories of his legend and it is said that: "Apām Napāt were born within the heart of heavens and from the clouds and he was raised there, the pure waters and clouds nourished him like a mother and as he was grown, his thunder comes out of the clouds, like a blade of fire and lightning from the skies." (Afifi, 1995: 403)

\section{ANAHITA, THE GODDESS OF WATERS, FERTILITY AND VEGETATION}

It can be boldly said that not so many lands, water is given such an enormous value and respect as it is in Iran. The evidences of the presence of this emotion and thought can be found in the beautiful and deep concepts visualized as legends and myths during the pre-Islamic era in Iran. For Aryans, rain was the ultimate element having a direct link to their lives. This implication is indicated when we see that water and enlightenment is the theme of the delicate and tender stories and the sweet fables. One of these fables, is the myth of Anahita, the goddess (Samadi, 1988: 13-16).

Anahita, Anahid or Nahid is one of the outstanding goddesses of ancient Iran. She is also known as the goddess of love and war. This goddess, who was a fair virgin, ruling over water was also a muse for earth's fertility and the element of creation of the universe and also the Mother goddess.

The complete name of this goddess is Aredvi Sura Anahita, meaning a strong and pure River (Water), which along with this goddess, concepts such as rain, abundance, herbs, fertility, blessing, matrimony, love, maternity, generation and victory are implicated.

In ancient Iran, Anahita were the goddess of fertility and the head mistress of Iranians. In Iranian models, she was the symbol of water, generation and river. According to Anahita's description in Avesta, she had an octagonal crown with many hundred stars on her head, a golden dress on her body and a golden necklace on her neck. She is described to be the fountain of all the waters on earth and the source of all 
fertilities; she purifies the seed of all males, sanctifies the matrix of all mothers and cleanses the milk in every mother's breasts (Yahaqi, 1388: 814).

She sits on a carriage and rides it with its leash on her hands, the carriage is led by four strong white horses; she rides and rules over all men, demons, witches, fairies, mountains and the oppressive crepes (Doustkhah, 1991: 319).

In Aban Yesht ${ }^{1}$ of Avesta, Anahita is described as a fair, young and tall lady whom were praised even before Zoroaster. Life springs out of her fountain and also one of her sculptures which is named the Mother goddess were found in the excavation of Sarab hill with a life of 9000 years (Amuzegar, 1995: 21-22).

Anahita is described in Avesta as: "Aredvi Sura Anahita, truly as it is her style, took the Barsom, puts on golden square earrings and golden necklace from her elegant neck and appears. She wears a corset to highlight her breasts and be more appealing." (Doustkhah, 1991: 320)

The belief of water being a goddess is not without any foundation; as breast is the symbol of nourishment (nursing) and as water gives life to entities and is the inception of blessing and fertility, these characteristics suits more with a woman's emotions.

It is mentioned in Avesta: "That much strong darling, Aredvi Sura Anahita walks and thinks to herself who's there to worship me? Who's there to challenge me, mingle with Haoma and be in need of this lioness, this creator of fine religion? I would favor this committed fine hearted person and I wish him to be happy and blooming!" (Doustkhah, 1991: 299-298)

\section{PRAISING ANAHITA}

Anahita were so significant in the ancient times that along with Ahura-Mazda and Mehr (Mithra) and her formed the holy trinity during Achaemenian, Parthian ${ }^{2}$, and Sassanid reigns. This concept is evident in the manuscripts and reliefs remaining from those reigns.

The evidences of praising Nahid or in fact, the sanctity of water as an eternal cultural element still reflects on the contemporary Iranian traditions. As in our culture, water is the source of enlightenment and blessing. For example, in some regions of Iran, still one of the major elements present in the "Sofre 7seen" of the New Year is water. In many of the current rural regions, the water which is to be put in the Sofre 7-seen is brought from fountains by virgin girls. Anahita is the goddess of water and this is why virgins are those who bring water from fountains also known as "Anahid" and this goddess is the parent of this life giving element, they steal the water and bring it back with themselves. This is an irony meaning that may there will be water for them throughout the year, also water in the Nowruz table decoration is as its other elements, a sign for fertility and blessing (Hashem Razi, 2005: 240-241)

Generally speaking, in the religion of Zoroastrianism, there are four holy elements which are fire, water, wind and earth which each of them have their own spectacular power. Apparently, water is the dearest element of creation after fire (Hashem Razi, same: 268).

\section{THE ETYMOLOGY OF RAIN CREATING}

Since ancient times, Iran was challenged with drought. We can see its first evidences in Takht-e Jamshid; where Darius askes Ahura-Mazda in his manuscript to protect Persia from drought, lies and enemies. Then this is not far from thought that as much common is praising the goddess of water in Iran; the rain creation rituals were also common. Though, what is this ritual exactly? 
This ritual is a complex and vast concept and was increasingly appearing in different cultures with different shapes and forms. One of the fixed features of this ritual is its link and connection with a divine religion. There are countless goals to perform the ritual, such as fulfilling the spiritual needs, strengthening the social bonds, showing respect and obedience and affirmation of an event and ...

The important point in this ritual is that its symbolic concept and task is not chosen by those performing it or is not driven by logic or evil, but it is imposed by an external force to them which they have incontinently inherited from their social traditions (Grimms, 1994).

It has been said that the main part of the rituals which were performed by the primary or even modern human is asking for blessing (Bahar, 1998: 297). Human is always vulnerable in the battle with natural forces. Because these forces can simultaneously be life giving and destructive. This permanent vulnerability of man always brings him to his knees; thus, the rituals were always performed accurately and carefully to ensure favorable results.

In a comprehensive point of view, the rain creating ritual is performed as following:

1- Manufacturing a doll by children, women or youngsters or sometimes the neighbors.

2- Alternatively, picking someone from the villagers and assigning him/her with a symbolic character

3- Marching on a holy place or the alleys of the village or carrying the doll or accompanying the chosen one.

4- Pouring water on the doll or the marchers or the chosen symbolic characters.

5- Saying prayers or chanting in demand for rain

6- Receiving gifts from neighbors

7- Cooking Aash $^{3}$ or bread and labeling and distributing the ritual meals.

8- Beating someone whose sign is in the meal until someone can meddle for him.

In this passage, the doll's manufacturing and its relation with Anahita is investigated.

\section{DOLLS' MANUFACTURE}

In different regions of Iran, manufacturing dolls are more or less the same. In Kurdistan, where the rain creating ritual is known by the name "Bouke Baran" meaning the bride of rain, they stick two pieces of wood in a cross shaped form and put on their traditional clothes on it (Hashemi, 2006). In Azerbaijan, using a dipper and making a cross and wearing dresses on the cross, they manufacture the dolls (Ashourpour, 2008). Manufacturing dolls in Gilan were also performed using a spoon (Mirshekarai, 2005: 462) and sometimes the women of Bardsir, suffice to making a little face (Borumand Saidi, 1998: 251252).

In Quchan, the young wear sheets or sometimes clothes on two or three meter sticks which they call "Chuli Qazak"4 (Mirnia, 2002: 184-185). In Kermanshah, people wear clothes on a long clothes and take it to a virgin girl and they also call this dress "Kuli Qazak" (Shams, 1998: 56). In the villages of Zarand in Kerman, they call this scarecrow the "Talou"5 (Khal'atbari, 2008: 86). The gender of these dolls are usually female and they are called the bride of rain and it acts as a meddler for descend of rain.

Dolls are metaphysical symbols and is sometimes known as the mother of crops or the mother of virgins (Kupar, 2000: 258). In rain rituals, there is no doubt that there is a relationship between dolls and a 
goddess which can influence the creation of rain. Thus, many believe dolls to be the symbol of Anahita who is the goddess of water and fertility in the rain creating rituals (Ashourpour, 2008).

Since Tishtrya is the god of rain and Anahita is the doll in this ritual, Anahita must please Tishtrya to make it rain and since the dolls are called the brides of rain in poems, it is probable that there be a relationship between Anahita and Tishtrya in the unwritten beliefs of people.

\section{TISHTRYA, THE HELPER OF THE GODDESS OF WATER}

This belief that women always are in need of men's support and their evolution is completed with the presence and the existence of men have always been common since the dawn of time until today. As Evelin Reed has said: "The idea that men are superior to women in societies depends on two biological features: men are often larger and more muscular and sturdier than women, and women are responsible for child bearing. Thus, this idea indicates that women are in need of the strong and witty men in order to dwell their vulnerable lives" (Reed, 2009: 44).

When her majesty, Anahita wills to show her power and godlikeness, she has to have companies. Her companies are the cloud, wind, rain and the hailstone.

Tishtrya in Iran is known as the supporter and the guardian of Anahita. Only with the presence of this god, the goddess of water can be fertile and cause the creation of rain. As Tishtrya, beats the demon of drought in a hard battle and after the demon is defeated, waters are released and the rain descends.

\section{RITUAL MARCHING}

In most rain creating rituals, marching can be found. The destination is up on the hills or meadows and farms; As the Bouke Baran ritual (Hashemi, 2006) people sometimes march to the Imamzadeh ${ }^{6}$ or to villages such as Chamcheh Khatoun (Ashourpour, 2008).

Marching is more common among girls and children and as children are naturally innocent, the play a more significant role in this ritual.

\section{POURING WATER ON DOLLS OR THE MARCHERS}

In most rain creating rituals, people pour water on dolls or the marchers. This is a symbolic and magical task. In many wizardries it is said that if you want the nature to do something, you have to do it yourself first (Bahar, 1998: 277). This task is of an ancient origin; huntsmen used to throw spears at the animal shapes on the cave walls they dwelled into, thus, pouring water on dolls and marchers is a symbol of the marchers' prayers for rain being granted. In fact, pouring water from a heights stimulates this magic so that it would act more effectively.

\section{CONCLUSION}

The land of Iran has always been dry, facing waterlessness or lack of water, and because of this geographical feature, water has always been of great sanctity in the minds of Persians. Water provision in our country, especially in the past eras were always a vital element of urban and rural residents. Rain has always been counted as one of the significant sources of water provision and Persians have always been asking the heavens for this need. The presence of a water goddess such as Anahita, Aredvi Sura and Tishtrya in Persian cultures is evident for this significance.

Aside from the concept of rain and its utilization for agricultural purposes, the significance of water in man's life, particularly in the dry land of Iran has always been of great sanctity. As reported by Herodotus - as it is mentioned above - water were of an enormous holiness in ancient Persians minds. The advent of rain creating rituals which are still being performed across Iran is an evidence for the importance of water and asking for rain and blessing in this country. 
The most important task which is performed in the rain creating ritual is manufacturing a doll which is the symbol of Anahita and pouring water on this doll wishing that the Mother Nature would do the same. This task is a kind of wizardry. While this might not reflect the aware minds of the holders of this ritual, but in the mind of the unaware, it reflects as such it is still heartwarming for the holders.

\section{REFERENCES}

Amuzegar, Zhaleh, 1995, "Iran's mythology" - First Edition, Tehran: The organization for Researching and Composing University Textbooks in the Humanities.

Broumand Saeed, Javad, 1998, Nowruz, Jamshid. Tehran: Tous, 1998.

Bahar, Mehrdad, Myths - the wonders and secrets of the desert, Tehran: Cheshmeh.

Berahmand, Qulamreza, The value and significance of water in the ancient Iran, Maskouyeh quarterly, issue 12

Khal'atbari Leymaki, Mustafa, 2008, Water, associated rituals and beliefs in popular culture, Tehran: Islamic Republic of Iran Broadcasting, department for research.

Doustkhah, Jalil, 1991, Avesta (the oldest Persians' poems), Tehran: Morvarid.

Reed E., 2009 Femenism and Anthropology, translated by Afshang Maqsoudi, Tehran: Gol Azin.

Shams, Sadeq, 1998, A glimpse at the Kermanshah people's culture, Tehran: Fekr-e No.

Samadi, Mehrangiz 1988, Moon in the history of ancient Iran until the advent of Islam, Tehran.

Afifi, Rahim, 2004, Myths and the culture of Iran, Tehran: Tous.

Ashourpour, Sadeq, A review of the rain creating rituals of Chamcheh Khatun, specialized theatre periodical, issue 42 .

Cooper J. C., 2000, An Illustrated Encyclopedia of Traditional Symbols, Tehran: Farshad.

Mir-Shokrai, Muhammad, 1995, Gilan's people traditions and rites, Tehran: Iran's Researchers.

Mirnia, Seyed Ali, 2002, The pop culture of the people of Khorasan, Mashhad: Sokhan Gostar.

Ne'mat Tavousi, Maryam. Decoding the steps of the rain creating ritual in Iran, Iranian Studies magazine, issue 21.

Hashemi, Varia, 2006, Boukeh Baran, Tehran: Cultural heritage organization's research department. Yahaqi, Muhammad Jafar, 1990, Encyclopedia of Myths, Tehran: Soroush. 